\title{
IN VITRO ANTI-INFLAMMATORY AND CYTOTOXICITY OF CRINUM X AMABILE GROWN IN ECUADOR
}

\author{
VINUEZA DIEGO $^{1 *}$, PORTERO SANTIAGO ${ }^{2}$, PILCO GISELA $^{1}$, GARCÍA MARLENE $^{2}$, ACOSTA KAREN $^{1}$, ABDo SUSANA ${ }^{1}$ \\ ${ }^{1}$ Natural Products Laboratory, Sciences Faculty, Polytechnic School of Chimborazo, Panamericana Sur km 11/2, CP 060155, Riobamba, \\ Ecuador. ${ }^{2}$ Immunology Laboratory, Sciences Faculty, Polytechnic School of Chimborazo, Panamericana Sur km 11/2, CP 060155, Riobamba, \\ Ecuador. Email: bfdiegov@hotmail.es
}

Received: 27 April 2018, Revised and Accepted: 05 June 2018

ABSTRACT

Objective: The aim of this research was to assess the in vitro anti-inflammatory activity and cytotoxicity of the methanolic extract and total alkaloid extract obtained from leaves and bulbs of Crinum x amabile (CA) growing in Ecuador.

Methods: Methanolic extracts of dry powered leaves and bulbs of CA obtained by cold maceration method were subjected to preliminary phytochemical screening. Total alkaloid extracts of leaves and bulbs of CA were obtained by conventional extraction of alkaloids base with an organic solvent. Furthermore, the anti-inflammatory activity and cytotoxicity of the four extracts were investigated by in vitro isolated neutrophils model using stable tetrazolium salt (WST-1).

Results: Phytochemical analysis of methanolic extracts revealed the major classes of phytochemicals such as alkaloids, flavonoids, tannins, triterpenes, and steroids, but no proteins or saponins could be detected on leaves extract. Extracts obtained from bulbs both methanolic and total alkaloids of CA show an interesting anti-inflammatory activity, although it was not significant compared to the standard anti-inflammatory drug, aspirin. Cytotoxicity of bulb alkaloid extract was lower compared with all of the other extracts.

Conclusion: Based on the results of this research, it could be concluded that CA is a very interesting source of natural anti-inflammatory compounds (especially alkaloids) which could be used to prevent many chronic disorders. Further, phytochemical studies are necessary to identify the chemical compounds responsible for the significant anti-inflammatory activity showed.

Keywords: Crinum x amabile, Anti-inflammatory activity, Cytotoxicity, Cell proliferation reagent, WST-1.

(C) 2018 The Authors. Published by Innovare Academic Sciences Pvt Ltd. This is an open access article under the CC BY license (http://creativecommons. org/licenses/by/4. 0/) DOI: http://dx.doi.org/10.22159/ajpcr.2018.v11i10.26962

\section{INTRODUCTION}

Since the beginning of civilization, people have used plants [1]. Medicinal plants have known for millennia as potential sources of pharmaceutical agents and/or as sources of lead compounds in drug discovery [2]. Between 70 and $80 \%$ of developing countries' population still is depending on medicinal plants because of the absence of both basic health-care facilities and the expensive cost of allopathic medicines [3]. In the plants, the secondary metabolites presence is responsible for the beneficial effects of plant materials [4]. Nature has been granted to Ecuador a variety of unique plant species due to its geographical, climatic, and altitude conditions; which makes it one of the countries with the highest biodiversity in the world and high endemism, documenting about 5400 plant species. At Ecuador, dry forests are mostly located in the center and south, west from the Andes, in the provinces of Imbabura, Esmeraldas, Manabí, Guayas, El Oro and Loja and are very important ecosystems [5]. Therefore, there is a need to explore these medicinal plants to find bioactive compounds that be as a basis for further pharmacological studies [6]. Scientific assessment and validation of the traditional therapeutic use of the medicinal plants may lead to the development of new and effective drugs as have occurred in the past $[7,8]$.

The Amaryllidaceae family, containing ca. 85 genera and 1100 species, distribute widely on the tropical to temperate regions around the world. Many Amaryllidaceae species have been cultivated as ornamental plants for a long time because of their colorful and beautiful flowers; thus, making a big market and significant economic values. Not only as ornaments but also Amaryllidaceae plants have also been applied on the pharmaceutical purpose [9]. Plants belonging to the Amaryllidaceae family are well known for containing an exclusive group of alkaloids, which have been considered a distinctive taxonomic characteristic of this family [10].

Crinum is a pantropical genus that has extensive traditional use in Africa in a range of therapeutic applications, including antitumor and antimalarial, and treatment of rheumatism and kidney and bladder infections, among others [11]. Alkaloids purified from the Crinum species have identified as responsible for some of these properties [12]. Alkaloid-rich extracts from Crinum angustum have shown significant antibacterial and antifungal activities [13]. Approximately 130 species found throughout Africa, America, southern Asia, and Australia have classified within the Crinum genus [14]. Great efforts have been made to make clear the chemical structure of several alkaloids of indigenous Crinum species in America as Crinum erubescens [15].

Crinum $x$ amabile (CA) is native from India, and it is a hybrid between Crinum asiaticum $\mathrm{x}$ Crinum zeylanicum. This widely grown species is not only a decorative plant but also it has been applied to a long time in Vietnamese folk medicine as an emetic and as a remedy for rheumatism and earache [16]. Afro-Ecuadorians living in the province of Esmeraldas have used use CA to treat inflammations and particularly hemorrhoids for more than 500 years.

The present study was conducted with the goals (1) to find the major classes of phytochemicals present in the leaves and bulbs of CA variety grown in Ecuador and (2) to test anti-inflammatory activity and cytotoxicity of CA leaves and bulbs by in vitro isolated neutrophils model using stable tetrazolium salt (WST-1) to confirm its use in traditional medicine. 


\section{METHODS}

\section{Drugs and chemicals}

Ficoll plaque, modified Hank's solution, Zimosan A, and Triton X-100 were purchased from Sigma-Aldrich, S.L. (USA), water-soluble tetrazolium salt (WST-1) from Roche (USA), aspirin from J.T. Baker (USA), dimethyl sulfoxide (DMSO), and ammonium chloride from Merck (Germany), deionized water was used in all experimental procedures. All other reagents were of analytical or high-performance liquid chromatography grade as appropriate.

\section{Collection of plant material}

CA, Amaryllidaceae, it was collected in Ecuador, Esmeraldas province, Muisne town, sector $\mathrm{N} 0^{\circ} 36^{\prime} 09.5^{\prime \prime} \mathrm{W} 080^{\circ} 01^{\prime} 30.1^{\prime \prime}$, at 5 meters above sea level. The plant material was taxonomically identified by Professor Alan Meerow. CA leaves and bulbs were collected, dried at $50^{\circ} \mathrm{C}$ in a forced convection oven for $24 \mathrm{~h}$, and they were ground in a knife mill until the particle size of $2-3 \mathrm{~mm}$.

\section{Extraction of the plant material}

\section{Methanolic extracts obtention}

$20 \mathrm{~g}$ of CA bulbs or leaves were separately macerated with $400 \mathrm{ml}$ of methanol for $48 \mathrm{~h}$ at room temperature with occasional shaking. Then, the extracts were filtrates, and the process was repeated on the marc until material exhausting. The collected filtrates concentrated under reduced pressure $\left(45^{\circ} \mathrm{C}\right)$ to produce the dry extracts $(5.02 \%$ and $6.28 \%$ for yield of leaves and bulbs, respectively). The solids were stored at $4^{\circ} \mathrm{C}$ and vacuum until use [17].

\section{Alkaloidal extracts obtention}

The dried samples were left in methanol for $48 \mathrm{~h}$. Alternatively, for a proper maceration, ultrasonic baths of $2 \mathrm{~h}$ per day were make, with solvent replacement every $24 \mathrm{~h}$. After the maceration time, the methanolic extract was filter, and the solvent was evaporate using a rotary evaporator under reduced pressure at $50^{\circ} \mathrm{C}$. The dried crude extract was then dissolved with $\mathrm{H}_{2} \mathrm{SO}_{4}(2 \% \mathrm{v} / \mathrm{v})$ to remove the neutral material (waxes, chlorophylls, mucilage, etc.) with ethyl ether ( 4 times). The acidic aqueous phase was then subjected to basification with $\mathrm{NH}_{4} \mathrm{OH}(25 \% \mathrm{v} / \mathrm{v})$ to $\mathrm{pH} \sim 10$ for alkaloid extraction with ethyl acetate. The extract was concentrated under reduced pressure at $45^{\circ} \mathrm{C}$ [18]. The yield of dry alkaloidal extracts was $0.41 \%$ and $0.62 \%$ to leaves and bulbs, respectively.

\section{Preliminary phytochemical screening test for CA}

The phytochemical screening on crude extracts obtained from CA leaves and flowers was made to investigate secondary metabolites presence such as alkaloids, flavonoids, terpenoids, saponins, tannins, and phenols using standard procedure $[19,20]$.

\section{Anti-inflammatory assay}

Neutrophils isolation is necessary for the performance of antiinflammatory and cytotoxicity tests. Heparinized fresh venous blood sample was drawn from healthy volunteers and neutrophils were isolated [21]. Whole blood was added to Ficoll paque, and the mixture was centrifuged for $30 \mathrm{~min}$ at $1500 \mathrm{rpm}$. After discarding the supernatant, red blood cells traces lysis was made by mixing with hypotonic ammonium chloride solution $(0.83 \% \mathrm{w} / \mathrm{v})$. It was centrifuged again, and the neutrophils were washed with MHS (modified Hank's solution, $\mathrm{pH}$ 7.4) and suspended at a concentration of $10^{7}$ cells $/ \mathrm{mL}$ in an MHS suitable volume [22]. Anti-inflammatory activity was determined using modified assay [23]. This in vitro assay is based on the reduction of WST-1 in the presence of activated neutrophils, because during the inflammatory response it is known that white cells produce reactive oxygen species [24]. Anti-inflammatory assay was determined in a total volume of $250 \mu \mathrm{L}$ MHS (pH 7.4) containing $10^{4}$ neutrophils $/ \mu \mathrm{L}, 500 \mu \mathrm{M}$ WST-1 and various concentrations of the test extracts. Control contained buffer, neutrophils, and WST-1. All compounds were equilibrated at $37^{\circ} \mathrm{C}$, and the reaction was initiated by adding opsonized Zymosan A $(15 \mathrm{mg} / \mathrm{mL})$, which was prepared by mixing it with human pooled serum, followed by centrifugation at $3000 \mathrm{rpm}$ and the pellet was suspended in phosphate buffer solution. Absorbance was measured at $450 \mathrm{~nm}$ [22]. Aspirin was used as a positive control that is widely used as nonsteroidal anti-inflammatory drugs for the treatment of several inflammatory diseases $[25,26]$. DMSO was used as blank, and the antiinflammatory activity was expressed as produced superoxide anions inhibition percent.

\section{Cell viability assay (cytotoxicity)}

Metabolically active cells reduce tetrazolium salts into colored formazan compounds. Therefore, tetrazolium salt-based colorimetric assays detect viable cells only. These sensitive assays can readily be performed in a microtiter plate with relatively few cells using a modified method [27]. In this study, the human isolated neutrophils $\left(10^{7}\right.$ cells $\left./ \mathrm{mL}\right)$ were incubated with test extracts for $30 \mathrm{~min}$ then WST-1 $(250 \mu \mathrm{M})$ was added and incubated in shaking water bath at $37^{\circ} \mathrm{C}$ for $3 \mathrm{~h}$. The absorbance was measured at $450 \mathrm{~nm}$. Triton X-100 (0.1\% v/v) was used as negative control showed $0.00 \%$ cell viability [22]. DMSO $(5 \% \mathrm{v} / \mathrm{v})$ was used as positive control exhibited $100.00 \%$ cell viability. The OD is the mean of three replicates. Cell viability percentage was calculated using the following formula:

$\%$ Cell viability $=\left(\mathrm{OD}_{\text {test }} / \mathrm{OD}_{\text {DMSO }}\right) \times 100$

\section{Data analysis}

The results are expressed as a mean \pm standard deviation. Student's t-test and one-way analysis of variance were applicable and were used to analyze the level of statistical significance between groups. $p<0.05$ was considered statistically significant.

\section{RESULTS AND DISCUSSION}

\section{Phytochemical screening}

According to the results of preliminary phytochemical screening of both the extracts showed the presence of alkaloids, flavonoids, carbohydrates, and glycosides. Proteins and cardiac glycosides were absent in both the extracts (Table 1).

\section{Evaluation of in vitro anti-inflammatory activity}

The inhibitory effect on inflammation derived from different concentrations of the CA extracts on isolated neutrophils model using stable tetrazolium salt (WST-1) is summarized in Table 2.

Both the bulb methanolic extract and bulb alkaloids extract showed appreciable inhibition of inflammation on isolated neutrophils (activated with opsonized zymosan A) in a dose-dependent way. The in vitro anti-inflammatory activity was not comparable to the aspirin, a reference anti-inflammatory drug at the same dose levels of extracts. A significant difference in the inflammatory inhibition was observed in case of bulb methanolic extract when is compared with the bulb alkaloids extract at concentrations of $12.5 \mu \mathrm{g} / \mathrm{mL}$ and $200 \mu \mathrm{g} / \mathrm{mL}$.

\section{Cytotoxicity}

The cytotoxicity was evaluated in terms of cell viability using freshly isolated neutrophils as a cellular model. The results of the cytotoxicity are shown in Table 3.

Major classes of phytochemicals were revealed from the results of phytochemical screening of both leaves and bulbs of CA, especially alkaloids, follow by flavonoids, glycosides, and carbohydrates, but no protein was detected. In addition, the bulb of CA showed saponins while the leaves tannin, steroids, and terpenes.

Plants belonging to the Amaryllidaceae family have alkaloids in their chemical composition. Alkaloids have been reported in C. asiaticum a species of the Crinum genus of which CA is hybrid [28]. The alkaloids of the CA bulb have been investigated, among which the mostrepresentative are licorine, bufanisine, Augustine, Ambelin, flexinin, crinamabine [16], amabiloside [29], and small amounts of galantamine, narvedine, galantine, hypeastrin, crinidine, and crinamine [30]. It has also been 
Table 1: Results of phytochemical analysis of CA leaves and bulbs methanolic extracts

\begin{tabular}{|c|c|c|c|}
\hline Phytochemical test & Name of the test & CA leaf extract & CA bulb extract \\
\hline Tannins & $\mathrm{FeCl}_{3}$ test, Lead acetate test & + & - \\
\hline Steroids & Salkowski test & + & - \\
\hline Flavonoids & Ammonia test, Alkaline reagent test & + & + \\
\hline Saponins & Frothing test & - & + \\
\hline Proteins and amino acids & Ninhydrin test & - & - \\
\hline Alkaloids & Dragendorff's, Hager's, Meyer's, and Wagner's test & + & + \\
\hline Carbohydrates & Molisch's test & + & + \\
\hline Terpenoids & Salkowski test (modified) & + & - \\
\hline
\end{tabular}

+: Present, -: Absent. CA: Crinum x amabile

Table 2: In vitro anti-inflammatory effect of CA methanolic extracts and alkaloids extracts by isolated neutrophils model using tetrazolium salt (WST-1)

\begin{tabular}{|c|c|c|c|c|c|}
\hline \multirow[t]{3}{*}{ Concentration $(\mu \mathrm{g} / \mathrm{ml})$} & \multicolumn{5}{|c|}{ Inflammatory inhibition (\%) } \\
\hline & \multicolumn{2}{|c|}{ Methanolic extract } & \multicolumn{2}{|c|}{ Alkaloids extract } & \multirow[t]{2}{*}{ Aspirin } \\
\hline & Leaves & Bulbs & Leaves & Bulbs & \\
\hline 12.5 & $29.91 \pm 0.19$ & $43.07 \pm 0.15^{*}$ & $4.04 \pm 0.78$ & $42.36 \pm 0.10$ & $54.09 \pm 0.21$ \\
\hline 25 & $30.75 \pm 0.15$ & $47.52 \pm 0.19$ & $10.62 \pm 0.15$ & $46.92 \pm 0.34$ & $57.96 \pm 0.33$ \\
\hline 50 & $32.17 \pm 0.29$ & $51.13 \pm 0.15$ & $15.18 \pm 0.34$ & $51.48 \pm 0.24$ & $61.51 \pm 0.18$ \\
\hline 100 & $33.79 \pm 0.24$ & $53.97 \pm 0.19$ & $18.96 \pm 0.24$ & $54.30 \pm 0.14$ & $65.79 \pm 0.25$ \\
\hline
\end{tabular}

Values are mean \pm SD, $n=3$. *Significant values, $P<0.05$, using Student's t-test, bulbs alkaloids extract versus bulbs methanolic extract. SD: Standard deviation, CA: Crinum $x$ amabile

Table 3: \% Cell viability of CA methanolic extracts and alkaloid extracts at different concentrations

\begin{tabular}{|c|c|c|c|c|c|}
\hline \multirow[t]{3}{*}{ Concentration $(\mu \mathrm{g} / \mathrm{ml})$} & \multicolumn{5}{|c|}{ Cell viability (\%) } \\
\hline & \multicolumn{2}{|c|}{ Methanolic extract } & \multicolumn{2}{|c|}{ Alkaloids extract } & \multirow[t]{2}{*}{ Aspirin } \\
\hline & Leaves & Bulbs & Leaves & Bulbs & \\
\hline 12.5 & $60.25 \pm 0.31$ & $53.55 \pm 0.23$ & $65.41 \pm 0.31$ & $65.71 \pm 0.31 *$ & $45.22 \pm 0.24$ \\
\hline 25 & $56.95 \pm 0.23$ & $45.21 \pm 0.23$ & $61.22 \pm 0.31$ & $63.05 \pm 0.23^{*}$ & $41.37 \pm 0.33$ \\
\hline 50 & $52.73 \pm 0.23$ & $40.27 \pm 0.46$ & $54.39 \pm 0.15$ & $57.01 \pm 0.23^{*}$ & $37.53 \pm 0.18$ \\
\hline 100 & $46.55 \pm 0.46$ & $35.94 \pm 0.23$ & $50.92 \pm 0.38$ & $52.92 \pm 0.15^{*}$ & $32.62 \pm 0.27$ \\
\hline 200 & $41.40 \pm 0.31$ & $32.85 \pm 0.54$ & $43.88 \pm 0.38$ & $47.80 \pm 0.31 *$ & $29.84 \pm 0.37$ \\
\hline
\end{tabular}

Values are mean \pm SD, $\mathrm{n}=3$. *Significant values, $P<0.05$, using Student's t-test, bulbs alkaloids extract versus bulbs methanolic extract. Triton $\mathrm{X}-100$ ( $0.1 \%$ ) was used as

negative control, showed $0.00 \%$ cell viability. SD: Standard deviation, CA: Crinum x amabile

shown that the type and proportion of alkaloids can differ between the species of the Crinum genus, hence the difference in biological activity that the various species show [31]. Terpenes and steroids in the leaves of CA contrast with the total absence of these components in the CA bulbs. The absence of steroids has been proved in the leaves of Crinum giganteum [32] and C. asiaticum [33]. There are no references to respect for alkaloids composition of CA leaves. Nevertheless, since to a large amount of these compounds exist in the extracts tested; the structural elucidation of the reliable components for the biological activity of the extracts is necessary. Various gas chromatography-mass spectra methods are available for that purpose [34].

The cell viability decreased by increase of CA extracts concentration. The CA cytotoxicity leaves and bulbs alkaloids extracts on isolated neutrophils are remarkable.

The results of the anti-inflammatory activity percent of CA leaves and bulbs extracts demonstrated a proportional relation between extract concentrations and anti-inflammatory activity. Amaryllidaceae family has not been widely studied for its anti-inflammatory activity but in its chemical composition (isoquinolinic type alkaloids). In this research, appreciable amounts of alkaloids would associate these components as responsible for the anti-inflammatory activity of CA.
Alkaloids have diverse biological activities, which are mainly related to its ability to inhibit enzymes [35], i.e., acetylcholinesterase [36] and its effects to induce apoptosis [37]. The pharmacological effects of isoquinolinic alkaloids such as its anti-Alzheimer [38], antiinflammatory, antiprotozoal [39], antimicrobial, and anticancer activities [40]. Lycorine has been shown to be effective at inhibiting iNOS (inducible nitric oxide synthase) in lipopolysaccharide (LPS)-activated mouse peritoneal macrophages [41]. Kang etal. highlighted that lycorine inhibited LPS-induced iNOS and COX-2 upregulation in RAW264.7 cells through the suppression of $\mathrm{p} 38$ and STATs activation [42]. LPS-induced tumor necrosis factor- $\alpha$ (TNF- $\alpha$ ) is an important pro-inflammatory cytokine involved in the regulation of inflammation and related disorders. Lycorine turned out to inhibit TNF- $\alpha$ production in LPSstimulated murine macrophages ( $\mathrm{IC}_{50} 0.2 \mu \mathrm{g} / \mathrm{mL}$ ) [43]. Furthermore, Liu et al. demonstrated that TNF- $\alpha$ signal transduction pathway and p21-mediated cell cycle inhibition were involved in the apoptosis of HL60 cells induced by lycorine [44].

When comparing the anti-inflammatory activity of the CA bulb extracts respect to anti-inflammatory activity of aspirin we found a statistically significant difference. Nevertheless, the potential of CA bulb extracts as an anti-inflammatory is measurable $(56-57 \%$ inflammatory inhibition). Cell viability comparison between CA bulb alkaloids extract and CA bulb methanolic extract, and aspirin differs from each other. 
Although the anti-inflammatory percentage of aspirin differs from the CA bulb extracts, it is not difficult to deduce that CA bulb extracts have interesting potential as an anti-inflammatory. All of the doses of CA bulb extract having an anti-inflammatory efficacy similar to that exhibited by aspirin.

The CA extracts have an anti-inflammatory activity like that of aspirin with a significant advantage over cytotoxicity, since the aspirin cytotoxicity is higher than that of leaves and bulbs extracts, which implies an important safety of use of this part of the plant and makes it a relatively safe alternative for its use as an anti-inflammatory. It is essential to make greater efforts focused on the isolation and structural elucidation of the functional components of CA, as well as studies to find other biological activities of this promising plant species like cholinesterase inhibition (Alzheimer in vitro experimental model). Finally, the research carried out is a contribution to appreciate the forgotten ancient use of this resource by Afro-Ecuadorians West Coast (of Muisne town especially) that uses it on hemorrhoids treatment. The results of this study could become an opportunity for the regional development of the communities through the planting, conservation, and rational use of this species; and, in this way, improve their economy.

\section{CONCLUSION}

Major classes of phytochemicals such as alkaloids and flavonoids followed by carbohydrates and glycosides were identified in the leaves and bulbs of CA variety grown in Ecuador. In addition, tannin, terpenoids, and steroids were identified in the leaves; and in the bulb only saponins. Although the anti-inflammatory activity of the CA bulbs did not reach results comparable to the control (aspirin), it has demonstrated under experimental conditions a considerable activity. CA leaves exhibited anti-inflammatory activity but did not achieve the efficacy denoted by CA bulbs. The research developed has established that the ethnobotanical use of CA is valid and that the use of this plant resource would be harmless in light of the results obtained.

\section{ACKNOWLEDGMENT}

Thanks to Polytechnic School of Chimborazo to provide facilities for development of this research. The authors are grateful to Mr. José Mora for his invaluable ethnobotanical knowledge and Professor Jaume Bastida Armengol CYTED-BIFRENES Thematic Network Director for his support.

\section{AUTHORS' CONTRIBUTIONS}

Vinueza Diego conceived and designed the experiments as well as wrote the paper. Portero Santiago, Acosta Karen, and Pilco Gisela performed the analyses. García Marlene made a statistical analysis of the data. Abdo Susana made critical reading and contributions to the paper.

\section{CONFLICTS OF INTEREST}

The authors declare no competing interests.

\section{REFERENCES}

1. Raja RD, Jeeva S, Prakash JW, Antonisamy JM, Irudayaraj V. Antibacterial activity of selected ethnomedicinal plants from South India. Asian Pac J Trop Med 2011;4:375-8.

2. Alhakmani F, Khan SA, Ahmad A. Determination of total phenol, in vitro antioxidant and anti-inflammatory activity of seeds and fruits of zizyphus spina-christi grown in Oman. Asian Pac J Trop Biomed 2014;4 Suppl 2:S656-60. Available from: http://www.linkinghub. elsevier.com/retrieve/pii/S2221169115300666.

3. Amjad MS, Arshad M, Saboor A, Page S, Chaudhari SK. Ethnobotanical profiling of the medicinal flora of Kotli, Azad Jammu and Kashmir, Pakistan: Empirical reflections on multinomial logit specifications. Asian Pac J Trop Med 2017;10:503-14.

4. Fürstenberg-Hägg J, Zagrobelny M, Bak S. Plant defense against insect herbivores. Int J Mol Sci 2013;14:10242-97.

5. Rondón M, Moncayo S, Cornejo X, Santos J, Villalta D, Siguencia R, et al. Preliminary phytochemical screening, total phenolic content and antibacterial activity of thirteen native species from Guayas province Ecuador. J King Saud Univ Sci 2017. DOI: org/10.1016/j.jksus.

6. Munuswamy H, Thirunavukkarasu T, Rajamani S, Elumalai EK, Ernest D. review on antimicrobial efficacy of some traditional medicinal plants in Tamilnadu. Acute Dis 2013;2:99-105. Available from: http:// www.linkinghub.elsevier.com/retrieve/pii/S2221618913601079.

7. Gullo VP, McAlpine J, Lam KS, Baker D, Petersen F. Drug discovery from natural products. Ind Microbiol Biotechnol 2006;33:523-31.

8. Winata HS, Rosidah R, Sitorus P. Assessment of anti-inflammatory activity of ethanolic extract of asamkandis (Garcinia xanthochymus Hook. F. Ex T. Anderson) fruit. Asian J Pharm Clin Res 2018;11:81-3.

9. Fan-Chiang TT, Wang HK, Hsieh JC. Synthesis of phenanthridine skeletal Amaryllidaceae alkaloids. Tetrahedron 2016;72:5640-5.

10. Bastida J, Lavilla R, Viladomat F. Chemical and biological aspects of narcissus alkaloids. Alkaloids Chem Biol 2006;63:87-179.

11. Nair JJ, van Staden J. Pharmacological and toxicological insights to the South African Amaryllidaceae. Food Chem Toxicol 2013;62:262-75.

12. Berkov S, Romani S, Herrera M, Viladomat F, Codina C, Momekov G, et al. Antiproliferative alkaloids from Crinum zeylanicum. Phytother Res 2011;25:1686-92.

13. Iannello C, Bastida J, Bonvicini F, Antognoni F, Gentilomi GA, Poli F, et al. Chemical composition, and in vitro antibacterial and antifungal activity of an alkaloid extract from Crinum angustum steud. Nat Prod Res 2014;28:704-10

14. Refaat J, Kamel MS, Ramadan MA, Ali AA, Pharmacy F, Refaat J. Crinum; An endless source of bioactive principles : A review, part II. Crinunm alkaloids: Crinine-type alkaloids. Int J Pharm Sci Res 2012;3:3091-100.

15. Guerrieri CG, Pigni NB, de Andrade JP, dos Santos VD, Binns F, de Souza Borges W, et al. Alkaloids from Crinum erubescens Aiton. Arab J Chem 2016;9:688-93.

16. Pham LH, Döpke W, Wagner J, Mügge C. Alkaloids from Crinumamabile. Phytochemistry 1998;48:371-6.

17. Vinueza D, López E, Acosta K, Abdo S. Assesment of antiinflammatory activity and cytotoxicity of freeze dried hydroalcoholic extract of Bidens andicola on isolated neutrophils. Asian J Pharm Clin Res 2017;10:160-3.

18. Acosta K, Pigni N, Oleas N, Bastida J. Identification of the alkaloids of Stenomesson aurantiacum (Kunth) herb an amaryllidaceae species from the ecuadorian andes. Pharmacologyonline 2014;3:178-83.

19. Chothani DL, Patel NM. Preliminary phytochemical screening, pharmacognostic and physicochemical evalution of leaf of Gmelina arborea. Asian Pac J Trop Biomed 2012;2 3 Suppl:1333-7.

20. Jeyaseelan EC, Jashothan PT. In vitro control of Staphylococcus aureus (NCTC 6571) and Escherichia coli (ATCC 25922) by Ricinus communis L. Asian Pac J Trop Biomed 2012;2:717-21.

21. Siddiqui RA, English D, Harvey K, Cui Y, Martin MI, Wentland J, et al. Phorbol ester-induced priming of superoxide generation by phosphatidic acid-stimulated neutrophils and granule-free neutrophil cytoplasts. J Leukoc Biol 1995;58:189-95.

22. Choudhary MI, Azizuddin, Jalil S, Atta-ur-Rahman. Bioactive phenolic compounds from a medicinal lichen, usnea longissima. Phytochemistry 2005;66:2346-50.

23. Tan AS, Berridge MV. Superoxide produced by activated neutrophils efficiently reduces the tetrazolium salt, WST-1 to produce a soluble formazan : A simple colorimetric assay for measuring respiratory burst activation and for screening anti-inflammatory agents. J Immunol Methods 2000;238:59-68.

24. Rastogi S, Iqbal MS, Ohri D. In vitro study of anti-inflammatory and antioxidant activity of some medicinal plants and their interrelationship. Asian J Pharm Clin Res 2018;11:195-202.

25. Macdonald TM, Beard K, Bruppacher R, Hasford J, Lewis M, Logan RF, et al. The safety of drugs for OTC use : What evidence is required for an NSAID switch ? Pharmacoepidemiol Drug Saf 2002;11:577-84.

26. Martin C, Connelly A, Keku TO, Mountcastle SB, Galanko J, Woosley JT, et al. Nonsteroidal anti-inflammatory drugs, apoptosis, and colorectal adenomas. Gastroenterology 2002;123:1770-7.

27. Berridge MV, Tan AN, Mccoy KD, Wang RU. The biochemical and cellular basis of cell proliferation assays that use tetrazolium salts. Biochemica 1996;4:14-9.

28. Asmawi MZ, Arafat OM, Amirin S, Eldeen IM. In vivo antinociceptive activity of leaf extract of crinum asiaticum and phytochemical analysis of the bioactive fractions. Int J Pharmacol 2011;7:125-9.

29. Ruangrungsi WN, Cordell G. Amabiloside, a new glycoside from crinum amabile. Nat Prod Lett 1993;3:1-4.

30. Likhitwitayawuid K, Angerhofer CK, Chai H, Pezzuto JM, Cordell GA, Ruangrungsi N. Cytotoxic and antimalarial alkaloids from the bulbs of 
Crinum amabile. J Nat Prod 1993;56:1331-8.

31. Refaat J, Kamel MS, Ramadan Ma, Ali A. Crinum; An endless source of bioactive principles: A review, part V. Biological profile. Int J Pharm Sci Res 2013;4:1239-52.

32. Elizabeth FB, Obikili EN, Esom AE, Anyanwu GE. Phytochemical screening and oral acute toxicity study of aqueous leaf extract of Crinum giganteum. 2016;8:22-5.

33. Chen CK, Lin FH, Tseng LH, Jiang CL, Lee SS. Comprehensive study of alkaloids from Crinum asiaticum var. sinicum assisted by HPLC-DAD-SPE-NMR. Nat Prod 2011;74:411-9. Available from: http://www.pubs.acs.org/doi/abs/10.1021/np100819n\%5Cnhttp:// pubs.acs.org/doi/suppl/10.1021/np100819n/suppl file/np100819n si_001.pdf.

34. Torras-Claveria L, Berkov S, Codina C, Viladomat F, Bastida J. Metabolomic analysis of bioactive amaryllidaceae alkaloids of ornamental varieties of narcissus by GC-MS combined with k-means cluster analysis. Ind Crops Prod 2014;56:211-22.

35. McNulty J, Nair JJ, Singh M, Crankshaw DJ, Holloway AC, Bastida J. Selective cytochrome P450 3A4 inhibitory activity of amaryllidaceae alkaloids. Bioorganic Med Chem Lett 2009;19:3233-7.

36. Ortiz JE, Garro A, Pigni NB, Agüero MB, Roitman G, Slanis A, et al. Cholinesterase-inhibitory effect and in silico analysis of alkaloids from bulbs of Hieronymiella species. Phytomedicine 2018;39:66-74.

37. McNulty J, Nair JJ, Bastida J, Pandey S, Griffin C. Structure-activity studies on the lycorine pharmacophore: A potent inducer of apoptosis in human leukemia cells. Phytochemistry 2009;70:913-9.

38. Pagliosa LB, Monteiro SC, Silva KB, de Andrade JP, Dutilh J, Bastida J, et al. Effect of isoquinoline alkaloids from two hippeastrum species on in vitro acetylcholinesterase activity. Phytomedicine 2010;17:698-701.

39. Osorio EJ, Berkov S, Brun R, Codina C, Viladomat F, Cabezas F, et al. In vitro antiprotozoal activity of alkaloids from Phaedranassa dubia (Amaryllidaceae). Phytochem Lett 2010;3:161-3.

40. Atta-ur-Rahman F, editor. Studies in Natural Products Chemistry. $1^{\text {st }}$ ed. Vol. 49. Amsterdam-Netherlands: Elsevier B.V.; 2016. p. 434

41. Abdel-Halim OB, Morikawa T, Ando S, Matsuda H, Yoshikawa M. New crinine-type alkaloids with inhibitory effect on induction of inducible nitric oxide synthase from crinum yemense. J Nat Prod 2004;67:1119-24.

42. Wang G, Huang $\mathrm{K}$, Dong Y, Chen S, Zhang J, Wang J, et al. Lycorine suppresses endplate-chondrocyte degeneration and prevents intervertebral disc degeneration by inhibiting NF- $\kappa \mathrm{B}$ signalling pathway. Cell Physiol Biochem 2018;45:1252-69.

43. Paul AT, Gohil VM, Bhutani KK. Modulating TNF-alpha signaling with natural products. Drug Discov Today 2006;11:725-32.

44. Liu J, Liang HJ, Shi BW, He Y, Hu WX. Up-regulation of p21 and TNF- $\alpha$ is mediated in lycorine-induced death of HL-60 cells. Cancer Cell Int 2010;10:1-9 